\title{
Two new species of Achnanthidium KüTZING (Bacillariophyceae) from Kolli Hills, Eastern Ghats, India
}

\author{
Balasubramanian KARTHICK ${ }^{1 *}$, Jonathan C. TAYLOR ${ }^{2,3}$ \& Paul B. HAMILTON ${ }^{4}$ \\ ${ }^{1}$ Biodiversity and Paleobiology Group, Agharkar Research Institute, G G Agarkar Road, Pune - 411004, India, \\ *Corresponding author e-mail: karthickbala@aripune.org \\ ${ }^{2}$ School of Biological Sciences, North-West University, Potchefstroom, South Africa \\ ${ }^{3}$ South African Institute for Aquatic Biodiversity, Grahamstown, South Africa \\ ${ }^{4}$ Research and Collections, Canadian Museum of Nature, Ottawa, ON K1P 6P4, Canada
}

\begin{abstract}
Two new freshwater species of Achnanthidium Kützing are described from Eastern Ghats Mountain range of Peninsular India based on light and scanning electron microscopy observations. Achnanthidium initium sp. nov. belongs to the group of Achnanthidium taxa that have terminal raphe fissures curved to opposite sides of the valve. This taxon is characterized by distinctive fascia, raphe endings extending to the valve margin, lineate distal raphe endings and 2-5 linear areola per striae. Achnanthidium linannulum sp. nov. belongs to the group of Achnanthidium taxa with terminal raphe fissures curved to the same side of the valve. This species is characterized by the presence of occluded areolae near the margin, striae orientation and the weakly bent internal distal ends of the raphe. These new species are known only from their type locality, oligotrophic Masilla Waterfalls from Kolli Hills, Eastern Ghats.
\end{abstract}

Key words: Achnanthidium initium, Achnanthidium linannulum, Masilla Waterfalls, Morphology, Peninsular India, Taxonomy

\section{INTRODUCTION}

Species of the genus Achnanthidium, as presently recognized, are known to occur across a broad range of conditions from oligotrophic to eutrophic waters. Taxonomically, this genus is challenging to study due to the small sized taxa, a limited number of diagnostic characters and a lack of autecological information. Further, Achnanthidium minutissimum Kützing, the most frequently reported species, has a complicated nomenclatural history (cf. POTAPOVA \& HAMILTON 2007). Achnanthidium minutissimum s.l. was for a long time a common cumulative group for many small Achnanthidium taxa found across all continents. This accumulation has resulted in a "species complex" composed of many infra specific taxa with a broad ecological range, from oligotrophic to eutrophic. However, if a more detailed examination of the valves was implemented, many of the distinct forms would have a narrow habitat optima; this clarity in the morphology would be more informative for water quality monitoring and biogeographic mapping. DNA analyses of Achnanthidium taxa have documented new species but there still appears to be a collection of diverse unnatural taxa
(PInseel et al., in press). Recently more detailed morphological studies on traditional Achnanthidium taxa have helped to resolve some of the species complexes. For example, detailed light and scanning electron microscopy of types for taxa such as A. minutissimum (HLÚBiKová et al. 2011; Potapova \& Hamilton 2007; Novais et al. 2015) and A. lineare (VAN DE ViJver et al. 2011) have in part helped to resolve some aspects of morphological variability.

From the Indian subcontinent, most of the species belonging to the genus Achnanthidium remain undocumented due to their small size or are included in Achnanthium minutissimum s.l. (WoJTAL et al. 2010). The published illustrated guide of diatoms of Indian subcontinent only recorded four common taxa of Achnanthidium (KARTHICK et al. 2013). Recently some taxonomic revisions and a distinctive new species $(A$. chitrakootense) have been documented from the Himalayas (JÜTTNER \& Cox 2011; JÜTTNER et al. 2011) and Central India (WoJTAL et al. 2010). In the present study, we describe two new species of Achnanthidium from Masilla water falls in Kolli Hills $\left(11^{\circ} 10^{\prime}-11^{\circ} 40^{\prime}\right.$ $\mathrm{N}$ latitude and $78^{\circ} 20^{\prime}-78^{\circ} 40^{\prime} \mathrm{E}$ longitude), Namakkal District, Tamil Nadu state of India. 


\section{Material And Methods}

Study Site. Kolli Hills (locally known as Kollimalai), is a small mountain range, part of Eastern Ghats located in the Namakkal District of Tamil Nadu State in India. Geologically, Kolli Hills are a compact block of hills with steep slopes, ridges and valley complexes. They are underlain by the oldest crystalline rocks of Archaean age, along with an intermediate period of metamorphic rocks of Magnetic quartzite, a tertiary period of Laterite and Bauxite, and the recent colluviums and soils (Geological Survey of India, 2006). The top portions of the hills are highly undulating, cut by a network of streams. Most of the streams are semi-perennial or seasonal, flowing mainly in an eastern and southeastern direction, which drains into the Aiyur River. Samples investigated in this study originate from Masilla Waterfalls $\left(11.3034^{\circ} \mathrm{N}\right.$, $78.3939^{\circ} \mathrm{E}$, altitude 1121 m.s.1.).

Field and Laboratory Methods. Benthic diatom samples were collected by scraping rocks from the Masilla Waterfalls and associated spray zone and then transferred into Whirl$\mathrm{Pak}^{\circledR}$ storage bags. Diatoms were cleaned using hot $\mathrm{HCl}$ and $\mathrm{KMnO}_{4}$ to remove organic matter. The samples were washed 4-5 times by deionized water removing acidified water through repeated centrifugation at $3000 \mathrm{rpm}$. A subsample from the washed material was dried onto glass coverslips and the coverslips subsequently mounted onto microscope slides using Pleurax (R.I. 1.73) as the mounting medium (KARTHICK et al. 2010). Light microscopy (LM) studies were carried out with a Nikon Eclipse 80i microscope, equipped with differential interference contrast optics (DIC) and a 1.45 N.A. $100 \times$ oil immersion objective. Photomicrographs were taken with a Nikon DS-Fil digital camera. For scanning electron microscopy (SEM) examination, aliquots of the cleaned material were air dried on pieces of $(5 \mathrm{~mm} \times 5 \mathrm{~mm})$ vinyl phonograph records (MACGILLIVARY \& EHRMAN 2011). The vinyl record squares were fixed to aluminum stubs using doublesided carbon tape, and sputter-coated with gold palladium. The prepared stubs were studied using either a ZEISS EVO MA15 SEM or a FEI Quanta 2000 F-SEM (10 kV, WD 10 $\mathrm{mm})$. Cleaned samples are stored in the diatom collection at the Agharkar Research Institute Herbarium (AHMA), Pune, India.

\section{RESUlts}

\section{Achnanthidium initium B.KARTHICK, J.C.TAYLOR et P.B.HAMilton sp. nov. (Figs 1-46)}

Description: Frustules in girdle view genuflexed, raphe valve strongly concave (Figs 27-28). Valves linear-lanceolate to lanceolate with rounded to weakly rostrate rounded apices. Valves 11.5-25.5 $\mu \mathrm{m}$ long, 3.0-3.5(3.6) $\mu \mathrm{m}$ wide. Raphe valve with narrow linear axial area. Axial area slightly expanded into asymmetrical transverse fascia at central area (Fig. 31). Raphe straight, filiform, terminal raphe fissures deflected to the opposite side at an angle of $80-90^{\circ}$, terminating on the mantle with drop-like termini (arrows in Figs $30,32)$. Striae radiate throughout; denser and more strongly radiate towards apices, $29-34$ in $10 \mu \mathrm{m}$. Striae composed of 2-5 rounded to transapically elongated areolae (Figs 29-32). Areolae absent along valve margins; mantle with single row of linear areolae extending around apices.

Externally, central raphe endings teardropshaped. Areolae round to elliptical, not occluded. Internally linear areolae on mantle and valve face next to mantle sometimes with a recessed ledge (Fig. 41). At apices, areolae surrounded by papillae like structures (arrows in Figs 40, 42). Raphe valve with thickened central nodule (Fig. 39). Sternum thickened and elevated near terminal fissure; one side more elevated (Figs 39, 40). Helictoglossae opening towards opposite side, within a thickened circular nodule. Central fissures weakly deflected in opposite directions (Fig. 41).

Rapheless valve convex with narrow linear axial area, slightly expanded at central area (Figs 35, 43). Central area weakly elliptical to almost absent (Figs 33, 35). Striae nearly parallel, slightly radiate and denser near apices, 32-35 in $10 \mu \mathrm{m}$ (Figs 33, 35). Areolae round to elliptical not occluded. Internally, areolae linear, occluded on mantle and valve face at mantle sometimes with recessed ledge (Figs 44-46); areolae occluded with fine hymen structure (Fig. 46).

Holotype: Slide \#24-73, Agharkar Research Institute Herbarium (AHMA), Agharkar Research Institute, Pune, India. Type Material \#1187.

Iconotype: Fig. 5.

Type locality: Epiphyton, Masilla Waterfalls (locally known as Masilla Aruvi), Aariyur Panchayat, Kolli Hills $\left(11.3034^{\circ} \mathrm{N} 78.3939^{\circ} \mathrm{E}\right.$, altitude 1121 meters above sea level), Namakkal district, Tamil Nadu, India.

Habitat: Epiphyton in lotic freshwater

Etymology: The Latin epithet "initium" refers to "beginning or commencement" referring to a partly curved form "athlete preparing for the start of a race".

Achnanthidium linannulum B. KARTHICK, J.C. TAYLOR et P.B. HAMilton sp. nov. (Figs 47-84)

Description: Frustules in girdle view arched. Valves linear-elliptical to lanceolate, with rounded or slightly protracted apices; length 15.5-32.5 $\mu \mathrm{m}$, width 2.5-4.5 $\mu \mathrm{m}$. Raphe valve concave, axial area lanceolate, central area indistinct to weakly expanded. Raphe distinct filiform (Figs 47-58). Distal raphe endings deflected to the same side at an angle of $80-90^{\circ}$ and terminating on the mantle; ending as small expanded pores at junction of valve face and mantle (Figs 66, 68, 70). Central raphe endings teardrop-shaped and straight (Fig. 69). Striae parallel, becoming denser and radiate towards apices, 24-27 in $10 \mu \mathrm{m}$. Areolae narrow linear to linear-elliptical often with slight mid-constriction (Fig. 69); 2-3 areolae per stria (Figs 66-70). Mantle with 


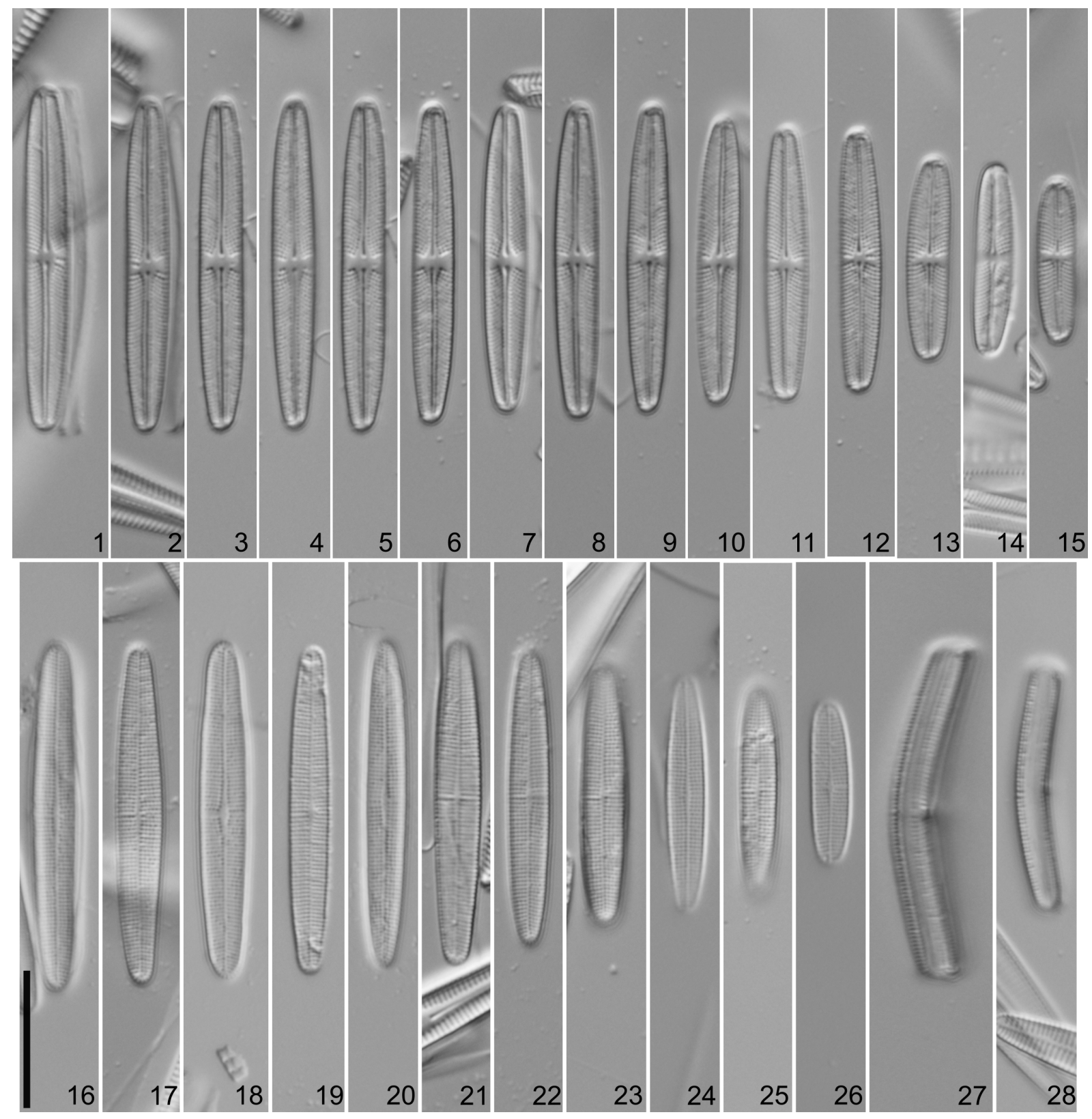

Figs 1-28. Achnanthidium initium sp. nov., LM valve views, Masilla Waterfalls, Kolli Hills, India: (1-15) diminution series of raphe valve; (16-28) diminution series of rapheless valve; (3) holotype specimen. Scale bar $10 \mu \mathrm{m}$.

single row of linear areolae extending around apex with small interruption at apex. (Figs 66, 68, 70). Internally distal raphe terminates in raised helictoglossae close to apex (Figs 71, 72, 74); proximal ends curved in opposite directions (arrow in Fig. 73). Areolae occluded with poroid cribra (Figs 72-74).

Rapheless valve slightly convex at centre, with narrow lanceolate axial area (Figs 75, 76). Central area weakly expanded to absent. Transapical striae parallel throughout; denser near the apices, 24-26 in $10 \mu \mathrm{m}$ (Fig. 78). Areolae narrow, linear; $2-4$ areolae per stria (Figs 75-79). Areolae absent at valve margin. Mantle areolae with cribra (Fig. 84), same as valve face areolae; single row of areolae extending around apex (Fig. 77). Internally areolae with a recessed ledge and irre- gular poroid cribra occlusions (arrow in Fig. 84).

Holotype: Slide \#24-73, Agharkar Research Institute Herbarium (AHMA), Agharkar Research Institute, Pune, India. Type Material \#1187

Iconotype: Fig. 51.

Type locality: Epiphyton, Masilla Waterfalls (locally known as Masilla Aruvi), Aariyur Panchayat, Kolli Hills $\left(11.3034^{\circ} \mathrm{N} 78.3939^{\circ} \mathrm{E}\right.$, altitude 1121 meters above sea level), Namakkal district, Tamil Nadu, India. Habitat: Epiphyton in lotic freshwaters

Etymology. The epithet "linannulum" refers to the irregular lineate or sometimes rounded poroids around the circumference of each hymen. 

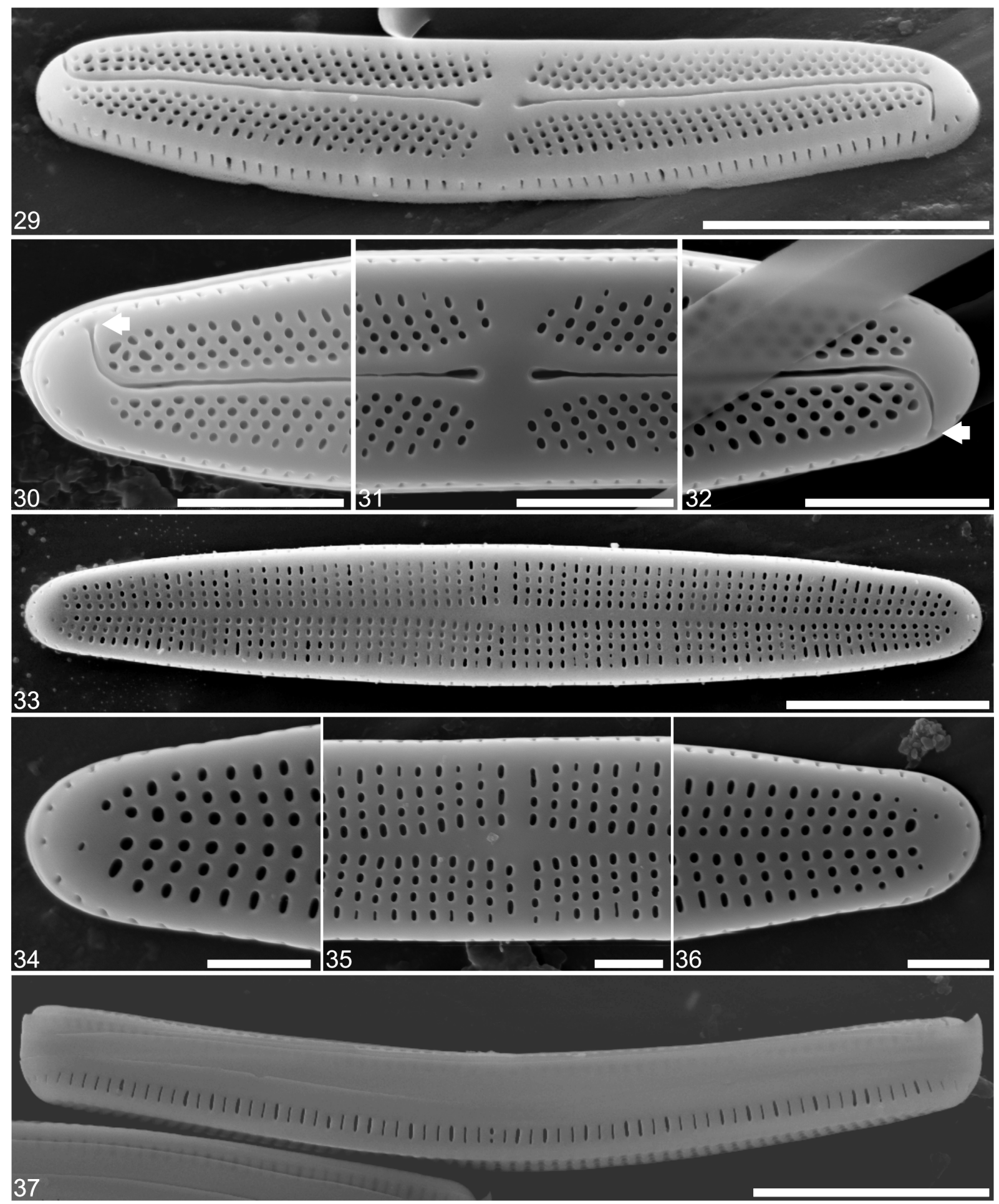

Figs 29-37. Achnanthidium initium sp. nov., SEM external valve views, type material: (29) raphe valve with terminal raphe fissures curved to opposite sides; $(30,32)$ details of apical areas of raphe valve, raphe fissures ending on mantle with drop-like termini, arrows pointing to expanded distal ends; (31) central area of raphe valve with teardrop-shaped raphe ends; $(33)$ rapheless valve; $(34,36)$ detail of apical area of the rapheless valve with a single row of linear areolae extending around the apices on the mantle; (35) part of valve with weakly elliptical central area; (37) girdle view of frustule with areolae on the mantle. Scale bars $5 \mu \mathrm{m}(29,33,37), 2 \mu \mathrm{m}(30-32), 1 \mu \mathrm{m}(34-36)$.

\section{Discussion}

Within the broad concept of Achnanthidium there are selected characters which represent morphological subgeneric groupings. The formation of a narrow li- near to linear-lanceolate valve and the type (shape) of areolae separate the A. minutissimum KürzING taxa clusters (round to elliptical areolae) from the A. pyrenaicum (Hustedt) KobayAsI (lineate areolae) taxa clusters. Additional taxa clusters can be distinguished by 

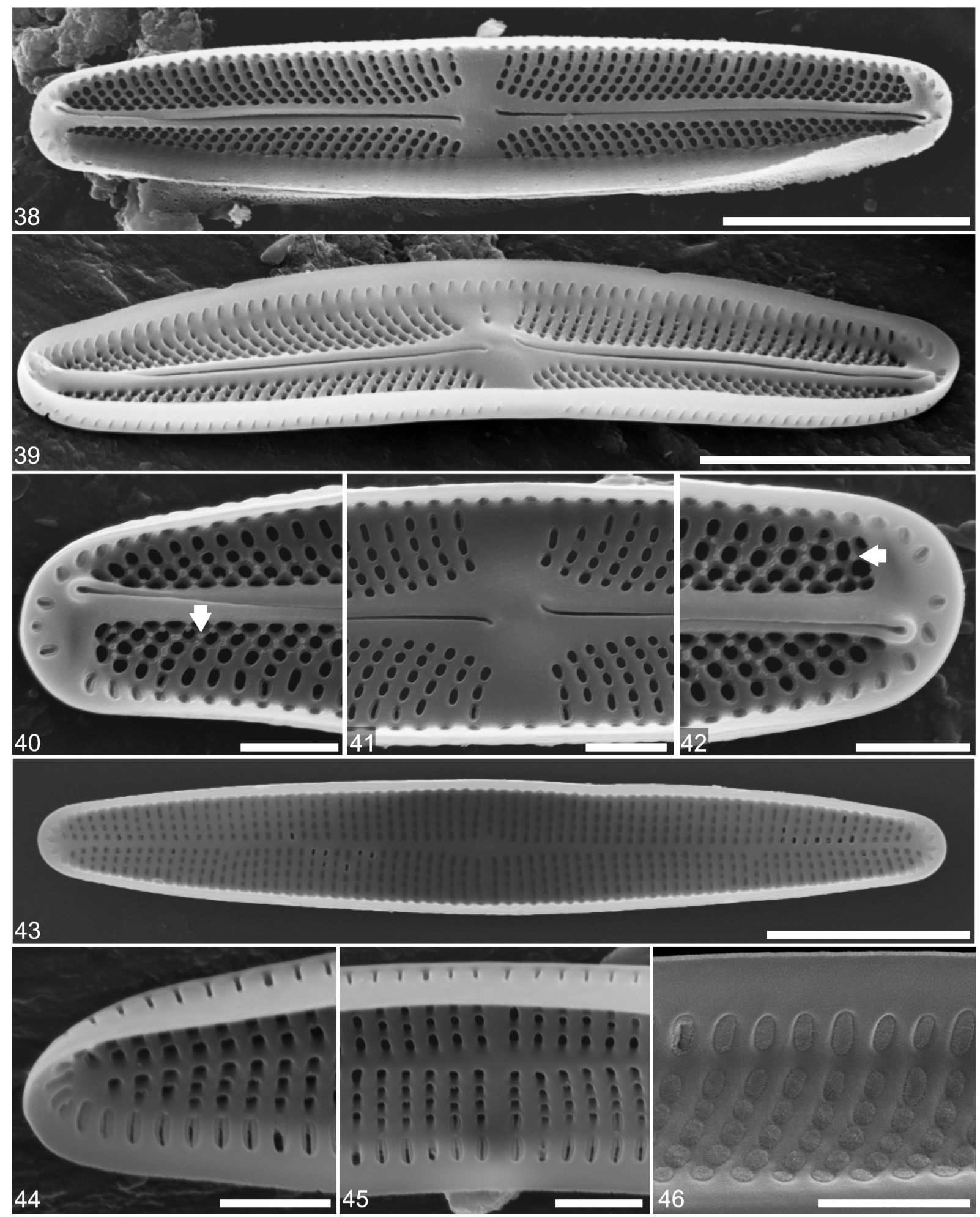

Figs 38-46. Achnanthidium initium sp. nov., SEM internal valve views, type material: $(38,39)$ Internal view of an entire raphe valve; $(40,42)$ distal raphe ends in a raised helictoglossae, helictoglossae opening towards opposite side; (41) detail of central area of raphe valve with fissures weakly deflected in opposite directions; (43) entire rapheless valve; (44) apical area of rapheless valve; (45) central area of rapheless valve; (46) Internal areolae openings with fine hymen structures. Scale bars $5 \mu \mathrm{m}(38-39,43), 1 \mu \mathrm{m}(40-42,44-46)$.

the structure of the raphe. The raphe with simple poroid terminations or slight deflection on the valve face fall into a more defined A. minutissimum-like complex, while valves with terminal raphe ends curved to one or opposite sides fall into an $A$. pyrenaicum-like grouping and $A$. initium-like grouping respectively (KoBAYASI 1997; Potapova \& Ponader 2004; KobaYasi et al. 2006; Potapova 2006; Ponader \& Potapova 2007). These clusters are based on different distal raphe endings, but also have differences in the hymen formation of 


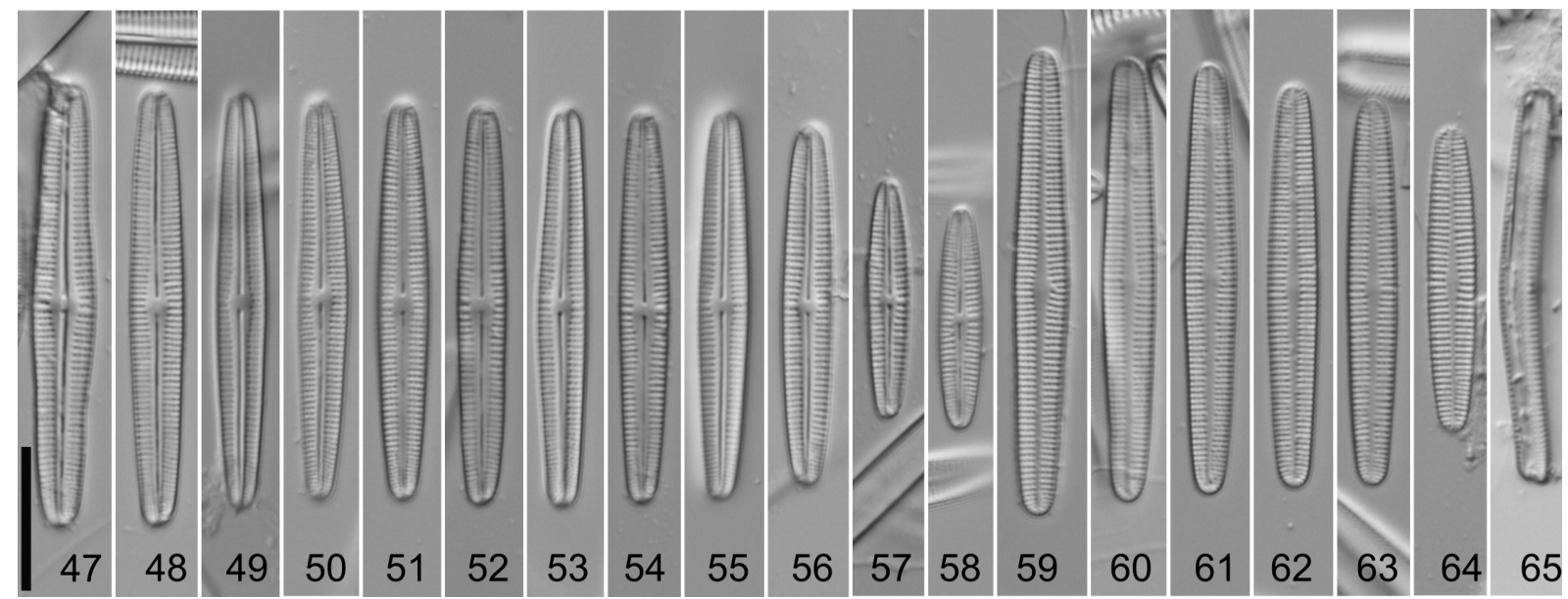

Figs 47-65. Achnanthidium linannulum sp. nov., LM valve views, Masilla Waterfalls, Kolli Hills, India: (47-58) diminution series of raphe valve; (59-65) diminution series of rapheless valve); (51) holotype specimen. Scale bar $10 \mu \mathrm{m}$.

the internal areolae; poroid in A. minutissimum-like clusters versus central in $A$. pyrenaicum-like and $A . i$ nitium-like groups. Although this separation of taxonomic clusters is not based on phylogenic analyses, it is a simple way to separate the many taxa with linear to linear-lanceolate valve forms. Preliminary molecular studies based on nuclear genetic material suggest that there is no distinct subgeneric separation between $A$. minutissimum-like and $A$. pyrenaicum-like taxa (pers. obs.). However, chloroplast genes like rbcL maybe more discriminating (HAMiLTon et al. 2015).

Currently four taxa are recognized with distal raphe ends on the raphe valves that deflect in opposite directions. These taxa are easily separated from each other by valve morphology (Table 1$)$. $A$. indicatrix (Moser et al. 1998; 82, figs 18: 10-14), A. peridotiticum (Moser, Lange-Bertalot \& Metzeltin) H. Lange-Bertalot (Lange-Bertalot 1999, Moser et al. 1998; 85, figs 18: 1-9) and A. contrarea (LANGE-BERtalot \& Steindorf) H. Lange-Bertalot (Lange-BerTALOT 1999, Moser et al. 1995;34, figs 5: 1-19) have expanded linear to linear elliptical valves with capitate apices, in contrast to $A$. initium which is larger having narrow linear valves with rostrate to rounded apices. A. initium also has a distinct transverse fascia without marginal areolae around the central area in contrast to the other three species. In addition, the proximal raphe fissures of $A$. initium are larger teardrop pores and the distal fissures are strongly deflected and terminate at the valve margin in contrast to the other taxa. Internally, the raphe defects in opposite directions at the poles (similar to $A$. contrarea) with offset distal nodules (Figs 72, 74). Unlike $A$. contrarea the sternum at the apex of $A$. initium is thicker and raised on the side opposite the deflection (Fig. 73, white arrow). The helictoglossae are fine clearly thickened around the distal circumference which is not evident in $A$. contrarea. No internal valve images are available for $A$. peridotiticum and $A$. indicatrix. The lineate mantle areolae have a recessed internal silica constriction which is evident in most of the linear-lanceolate taxa within the genus Achnanthidium (Figs 44, 45).

Achnanthidium initium, with respect to size and shape, can be compared to taxa with external distally hooked raphes to the same side (e.g. A. crassum (Hustedt) Potapova \& Ponader (2004), A. japonicum (Kobayasi) Kobayasi (1997), A. pseudoconspicuum(Foged) JütTner \& Cox (2011), $A$. rivulare PotAPova $\&$ Ponader (2004). In LM, $A$. initium is similar to $A$. pseudoconspicuum (JÜTTNER \& Cox 2011; 22, figs 1, 3-38) with the genuflexed frustule orientation, size and shape, but is distinguished by higher stria density around the central area of the raphe valve and the larger transverse central fascia. The araphid valve of $A$. initium is also similar, with parallel striae and a narrow axial area, but the stria density is higher (32-36 in 10 $\mu \mathrm{m}$ versus 20-24 in $10 \mu \mathrm{m}$ for $A$. pseudoconspicuum). In SEM, the striae on the raphe valve of $A$. pseudoconspicuum are more widely spaced around the central area, have 3 or more areolae ( 2 areolae in A. initium) and are not radiate at mid-valve. The proximal raphe fissures of $A$. pseudoconspicuum are also more teardrop shaped and deflected. The distal helictoglossae are positioned to one side of the valve apex in $A$. initium, while centrally positioned in A. pseudoconspicu$u m$. The geographic proximity of $A$. pseudoconspicuum (reported from streams and ponds of central and eastern Nepal) may be of significance when a more intensive biogeographic study is completed. The valves of A. japonicum (KoBAYASI et al. 2006; 124, figs155: 1-18) are wider, the axial area on the raphe valve is lanceolate, and the central area is absent or weakly asymmetrical. The araphid valve of $A$. initium has a much higher stria density compared to A. japonicum and the density increases at the apices. $A$. rivulare (РотAPova \& Ponader 2004; 36, figs 1-18, 28-43) and A. crassum (Potapova \& PonAder 2004; 38, figs 19-27, 44-49) are similar in valve outline, size and stria density, but they 

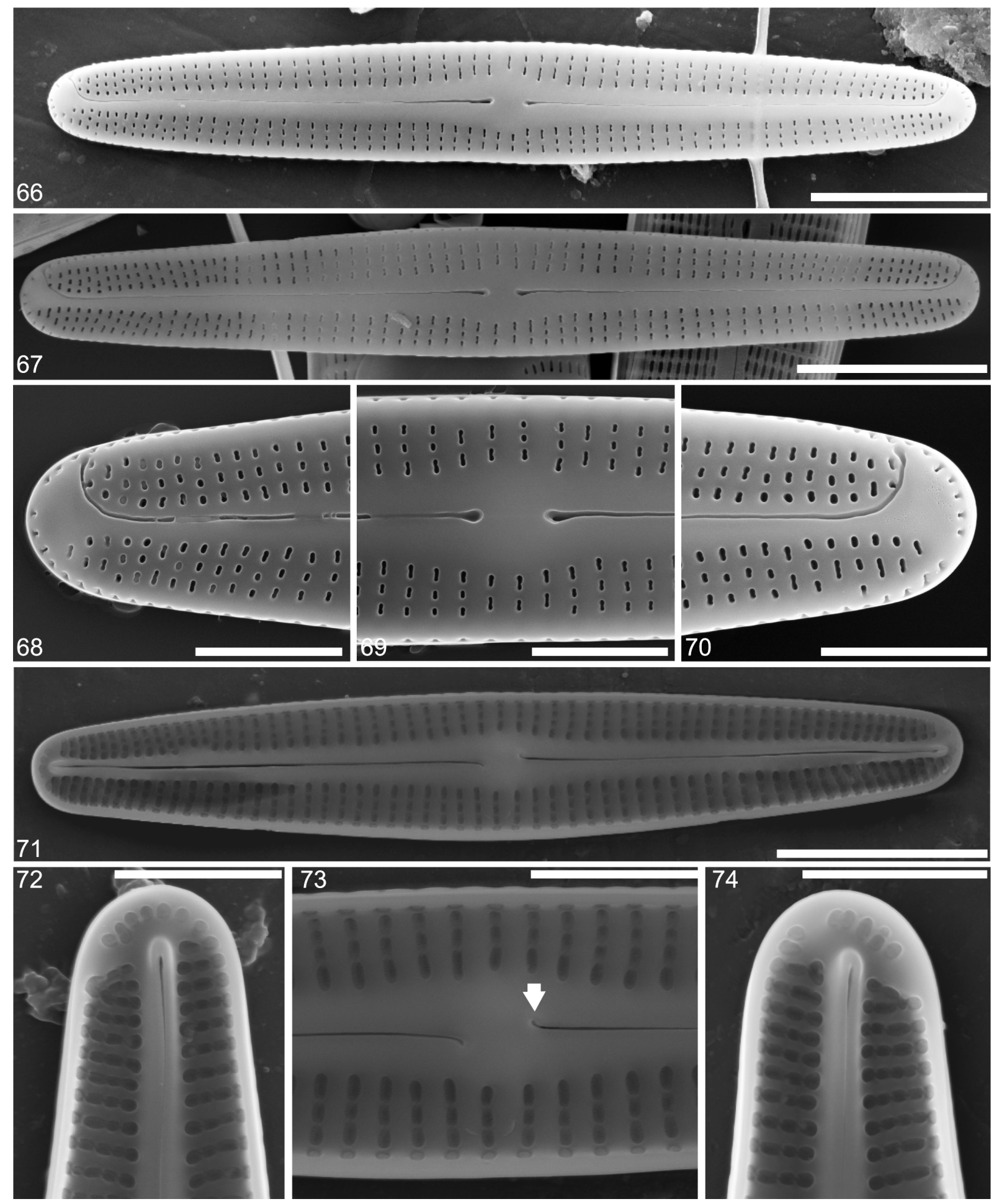

Figs 66-74. Achnanthidium linannulum sp. nov., SEM external (66-70) and internal (71-74) raphe valve views, type material: $(66,67)$ entire raphe valve with distal raphe fissures deflected to the same side; $(68,70)$ apical area of the raphe valve showing narrow linear to linear-elliptical areolae and a single row of linear areolae on the mantle extending with an interrupted around the apex; (69) central area with drop-like raphe; (71) an entire raphe valve; $(72,74)$ apical area of raphe valve with distal raphe terminating in a raised helictoglossae; $(73)$ central area of raphe valve showing proximal ends curved in opposite directions with thin hook-like structures. Scale bars $5 \mu \mathrm{m}(66,67,71), 2 \mu \mathrm{m}(68-70,72-74)$.

lack a transverse central fascia and the stria on the raphe valve are parallel to weakly radiate compared to the radiate striae of $A$. initium. In SEM the raphe valve of $A$. initium is distinguished by the transverse central fascia, and the oppositely deflected distal fissures; in- ternally, the sternum is asymmetrically thickened at the apices, the helictoglossae are positioned towards one side of the apex, and the proximal fissures are weakly deflected, compared to the distinctly deflected central fissures of $A$. rivulare. The araphid valves of $A$. initium 


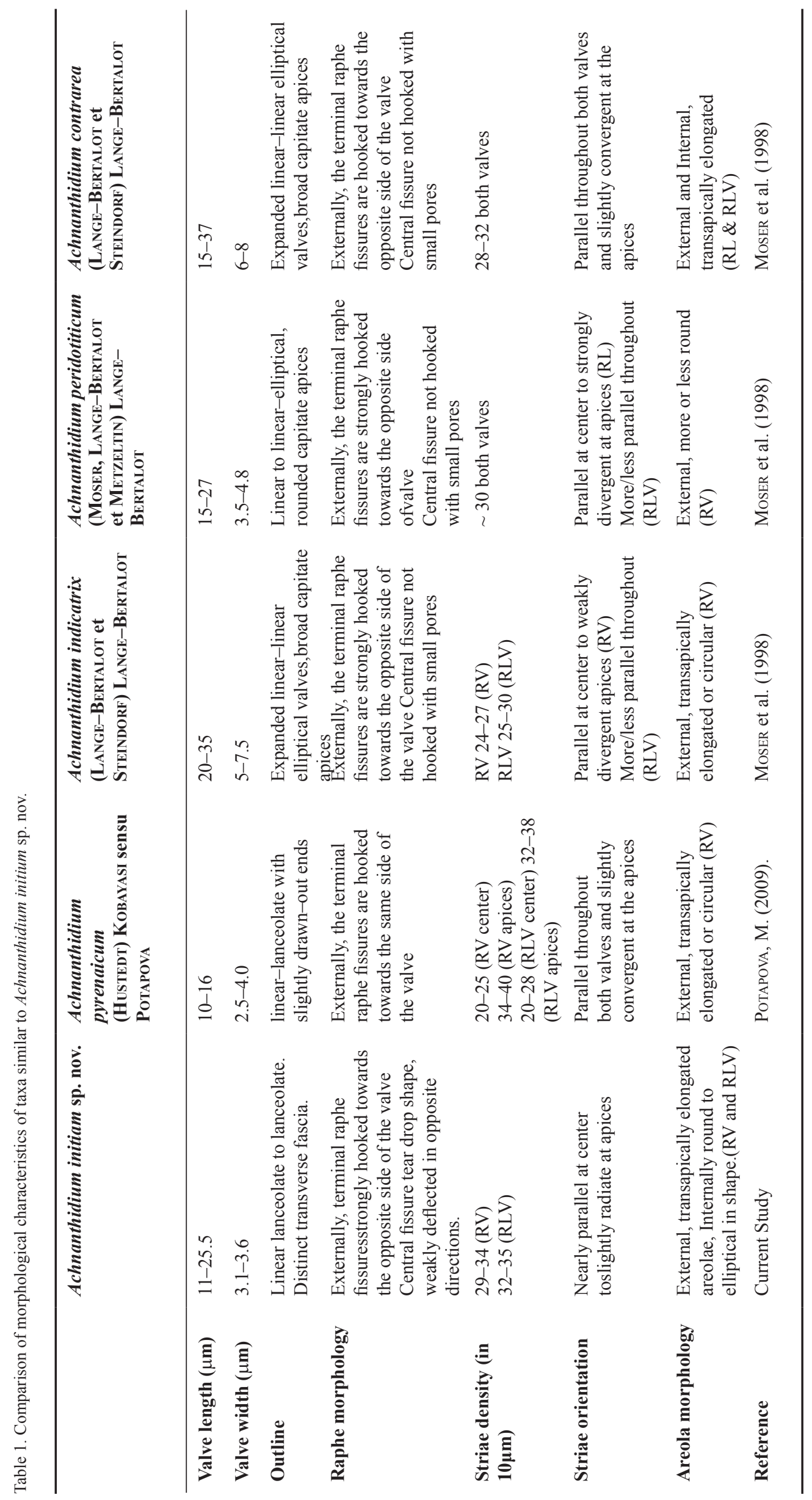




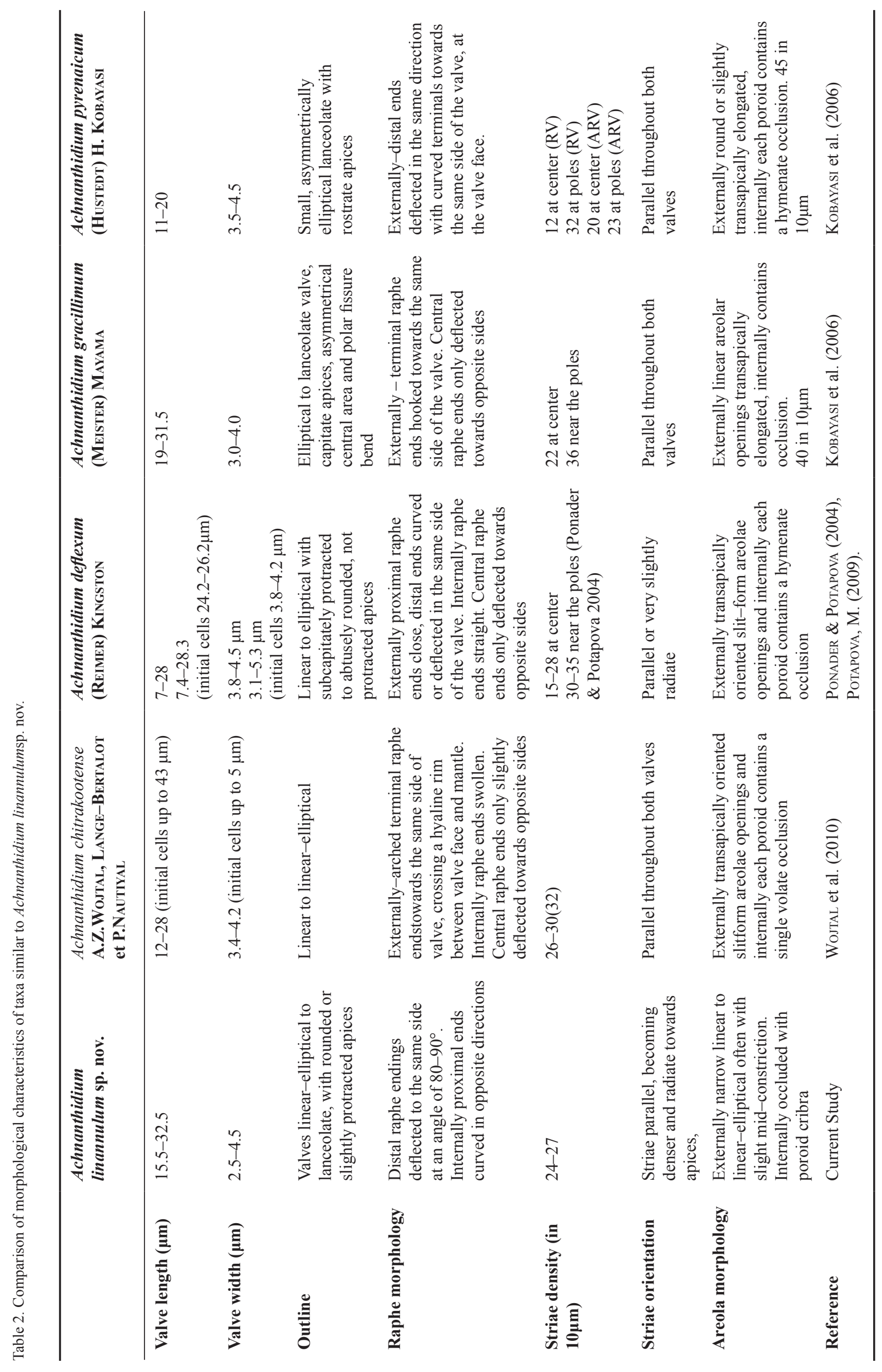



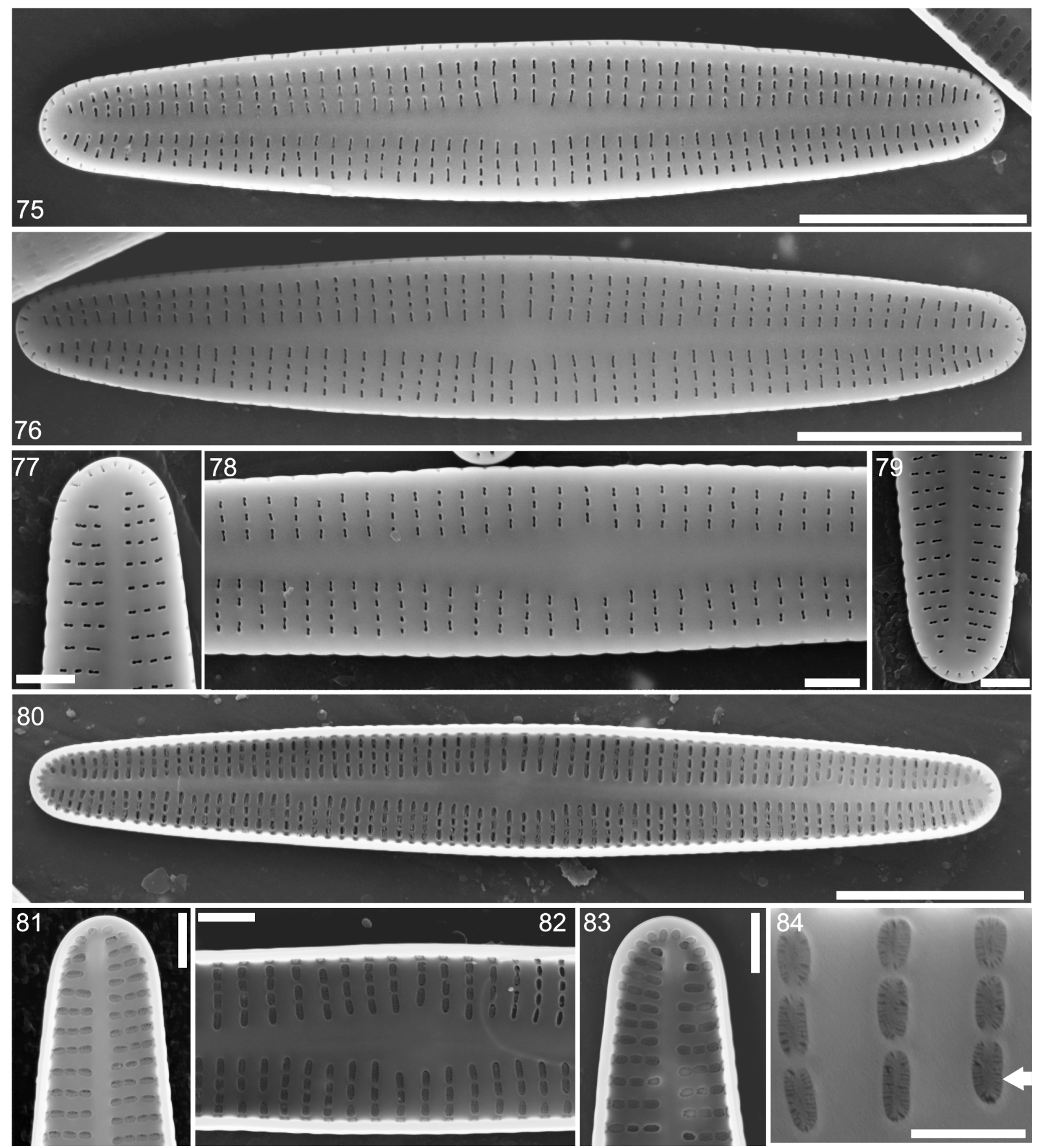

Figs 75-84. Achnanthidium linannulum sp. nov., SEM external (75-79) and internal (80-84) views of the raphless valve, type material: (75, 76 ) entire rapheless valve with elliptical central area; $(77,79)$ apical area of rapheless valve with single row of areolae extending around apex of mantle, not interrupted; (78) central area and axial area of raphe less valve; (80) internal view of an entire rapheless valve; $(81,83)$ details of apical area of rapheless valve; (82) internal view of central area of rapheless valve; (84) areolae covered by circular poroid cribra occlusions. Scale bars $5 \mu \mathrm{m}(75,76,80), 1 \mu \mathrm{m}(77-79,81-83), 500 \mathrm{~nm}(84)$.

are primarily distinguished by the higher stria density throughout the valve. Smaller valves in the diminution series of $A$. initium could also be confused with $A$. lailae VAN DE VIJVER (ZIDAROVA et al. 2009: 297, figs 1-21), but are separated by termination position of the distal raphe fissures, stria orientation (less radiate), stria density and areola density.

The valves of $A$. initium, with respect to size and shape, can also be compared to taxa with no de- flections of the distal raphe fissures: A. affine (GrunOw) CZARneCKi (1994), A. minutissimum sensu stricto, A. jackii RABenhorst (1861), A. ennediense (COMPÈre) Compère \& VAn de ViJver (2011), A. atomus (Hustedt) Monnier, Lange-Bertalot et Ector in Monnier et al. (2004), A. temniskovae Ivanov \& Ector (2006), and $A$. pseudolineare VAN DE VIJVer, Novais et Ector in VAN DE VIJVER et al. (2011a). In LM, A. initium is linear to linear-lanceolate with rostrate apices compared to the 
lanceolate valves with rostrate apices of $A$. minutissimum and A. ennediense. The transverse fascia of $A$. minutissimum is variable from present without marginal areolae to weakly developed with isolated striae (РотApova \& Hamilton 2007). The striae of $A$. minutissimum are less radiate at the center compared to A. initium; internally the axial area does not have an asymmetrical formation near the apices, and the helictoglossae are centrally positioned at the distal apex nodule. In girdle view $A$. ennediense has a curved orientation with deflected apices in contrast to the curved (genuflexed) girdle view of $A$. initium. The species $A$. jackii has a lanceolate valve not linear to linear-lanceolate, the fascia is more rectangular, stria density at the apices of the raphe valve is lower and the proximal fissures are not expanded (Potapova \& Hamilton 2007; Krammer \& Lange-Bertalot 1991; Wojtal et al. 2011).The species A. exile (KützING) Round \& BuKhtiYarova (1996) (Wojtal et al. 2011; 222, figs 108-130) is similar to A. jackii (WoJTAL et al. 2011; 215, figs 16-35), but has a higher stria density at the apices of the raphe valve compared to A. initium. Achnanthidium pseudolineare VAN DE VIJVER et al. (2011a; 186, figs 208-256) is similar, but has a higher stria density at the apices, lower areola density, distal raphe fissures are straight and the central fissures are small and indistinct. A. standeri (Cholnoky) J.C. Taylor, E.A. Morales et L. Ector in TAYLOR et al. $(2011 ; 155)$ can be similar in valve outline but distinguished by broader valves and the lower stria density.

Smaller valves in the diminution series of $A$. initium could also be confused with $A$. atomus, $A$. hoffmannii Van de Vijver, Ector, Mertens et Jarlman in VAN DE ViJver et al. (2011b), A. lineare W. SMith (1855) and A. temniskovae. All these smaller taxa have lanceolate to linear to linear-elliptical valves and the raphe valves with radiate striae, approximately similar areolae densities and a transverse central fascia which is similar to $A$ initium. However the distal raphe fissures are either simple pores on the valve face $A$. atomus (Simonsen 1987; 211, figs 325: 32-38), A. hoffmannii (VAN De ViJver et al. 2011b, 195, figs 1-17), A. lineare (VAN De ViJver et al. 2011a; 170, figs 1-35), A. atomoides Monnier, Lange-Bertalot et Ector (Monnier et al. 2004; 128, figs $1-41,117-123$ ) or hooked to one side (A. temniskovae (IvANov \& ECTOR 2006; 147, figs 1-43)) and the stria densities on both the raphe and araphid valves are lower. Achnanthes pseudolinearis Hustedt (Hustedt, 1942) is small, has no transverse central fascia and the distal fissures are hooked to one side (pers. obs. of material from type locality).

Achnanthidium linannulum is characterized by the lineate areolae on the raphe and araphid valves, linear-lanceolate shape, broadly rounded apices, linear striation, and distal fissures that hook to the same side of the valve. This taxon also has hymenes with perforations of the central array-type similar to A. japonicum. Four taxa with lineate striae on the raphe valve can be compared with A. linannulum (Table 2). A. chirakootense (WoJtaL et al. 2010; 58, figs 2-32) specimens from northern India have linear valves with a moderate inflation in the mid-portion of the valve and subcapitate apices in the larger specimens changing to lanceolate valves with rounded apices in smaller forms. The areolae are transversely elongated external foramina, and the distal fissures are strongly hooked to the same side of the valve. A. chirakootense is distinguished by valve outline in larger specimens, volate-type interconnected occlusions of the internal areolae foramina (on both raphe and araphid valves), the lower stria density on the araphid valve at the apices, and larger helictoglossae positioned close to the apex on a broader asymmetrical hyaline area. In LM, the overall similarity in smaller specimens between $A$. linannulum and $A$. chitrakootense is striking. WOJTAL et al. (2010) suggest that $A$. chitrakootense is more widely distributed in India, or previously identified under A. minutissimum s.l. Achnanthidium deflexum (Potapova \& Ponader 2004; 42 , figs 51-71, 81-103) frustules are also continuously curved (genuflexed) in girdle view, valves are linear to linear-lanceolate in outline with lineate areolae on the raphe and araphid valves; however, the axial area is narrower, there are more areolae (4-5 per stria versus 3-4 per stria [A. linannulum]) and the internal hymen with perforations of a small (POTAPOVA \& PONADER 2004, fig. 97) centric array compared to larger arrays in A. linannulum (Fig. 87). Stria density on the araphid valve of $A$. deflexum is also much higher. The species $A$. gracillimum (Meister) Mayama (Kobayasi et al. 2006; 123, figs 154: 1-14) is differentiated from $A$. linannulum by the curved orientation with deflected apices of the frustule in girdle view, elliptical to lanceolate valve shape, capitate apices, the asymmetrical central area on the raphe and araphid valves, and in SEM, the narrow lineate areolae. In LM, A. pyrenaicum (KoBAYASI et al. 2006; 127, figs 159: $1-11 ; 160: 1-18$ ) is generally smaller, asymmetrically elliptical-lanceolate in outline with rostrate apices. The central area on the raphe valve is asymmetrically expanded, the stria are less dense on both valve forms and the areolae are a mixture of round to linear foramina openings on the external valve face. WoJTAL et al. (2010) report that $A$. pyrenaicum and $A$. minutissimum were abundant and common in the rivers of northern India. Studies from southern India also show these taxa to be common species in disturbed habitats and environments (KARTHICK et al. 2011). Achnanthidium biasolettianum (KRAMmer \& Lange-Bertalot 1991; 62, figs 36: 1-31; 35: 5, 6) also has linear to elliptical areolae and distal raphe ends that curve to one side of the valve, but is separated from A. linannulum by the elliptical valve shape with rostrate apices, the asymmetrically expanded central area on the raphe valve and the lower stria density.

The new species described in the present study occurred abundantly in the samples along with populations of Encyonema, Neidium and Gomphonema-like 
diatoms. This study is the first report of diatoms from the Eastern Ghats, in particular, the Kolli Hills. Further studies on diatom diversity across multiple habitats of the mountains will compliment our the knowledge about a unique diatom flora of the Eastern Ghats.

\section{ACKNOWLedGements}

Karthick Balasubramanian is thankful to the Director of the Agharkar Research Institute for facilities and this work supported by Institute internal grant (BOT-23). J.C. Taylor is the recipient of South African National Research Foundation (NRF) incentive funding. Any opinions, findings and conclusions or recommendations expressed in this material are those of the author(s) and therefore the NRF does not accept any liability in regard thereto. P. B. Hamilton is supported by a Canada National Museum RAC grant (2014-2015). Authors also thank editor and anonymous reviewer for their valuable comments.

\section{REFERENCES}

Compère, P. \& VAn de ViJver, B. (2011) : Achnanthidium ennediense(Compère) Compère et Van de Vijver comb. nov. (Bacillariophyceae), the true identity of Navicula ennediensis Compère from the Ennedi Mountains (Republic of Chad). - Archiv für Hydrobiologie, Algological Studies 136: 5-17.

Czarnecki, D.B. (1994): The freshwater diatom culture collection at Loras College, Dubuque, Iowa. - In: KocIOLEK, J.P. (ed.): Proceedings of the $11^{\text {th }}$ International Diatom Symposium, San Francisco, 12-17 August 1990. - Memoirs of the California Academy of Sciences no. 17: 155-174.

Geological Survey of India (2006): Geology and Mineral Resources of the States of India - Part VI - Tamil Nadu and Pondicherry. Kolkata.

HlúBiKovÁ, D.; Ector, L. \& Hoffmann, L. (2011): Examination of the type material of some diatom species related to Achnanthidium minutissimum (Kütz.) Czarn. (Bacillariophyceae). - Archiv für Hydrobiologie, Algological Studies 136: 19-43.

Hustedt, F. (1942): Süßwasser-Diatomeen des indomalayischen Archipels und der Hawaii-Inslen. Internationale -Revue der gesamten Hydrobiologie und Hydrographie 42:1-252.

IVANov, P. \& Ector, L. (2006): Achnanthidium temniskovae sp. nov., a new diatom from the Mesta River, Bulgaria. - In: Ognuanova-Rumenova, N.\& Manoylov, K. (eds): Advances in Phycological Studies. Festschrift in Honour of Prof. Dobrina Temniskova- pp. 147-154, Topalova. Pensoft Publishers, St. Kliment Ohridski University Press, Sofia-Moscow.

JütTNER, I. \& Cox, E.J. (2011):.Achnanthidium pseudoconspicuum comb. nov.: morphology and ecology of the species and a comparison with related taxa. - Diatom Research 26: 21-28.

Jüttner, I.; Chimonides, J. \& Cox, E. J. (2011): Morphology, ecology and biogeography of diatom species related to Achnanthidium pyrenaicum (Hustedt) Kobayasi (Bacillariophyceae) in streams of the Indian and Nepalese Himalaya. - Archiv für Hydrobiologie, Algological Studies 136: 45-76.

Karthick, B.; Hamilton, P.B. \& Kociolek, J.P. (2013): An Illustrated Guide on Common Freshwater Diatoms of Peninsular India. - 208 pp. Gubbi Labs LLP: Gubbi.
Karthick, B.; Mahesh, M.K. \& Ramachandra, T.V. (2011): Nestedness pattern in stream diatom assemblages of central Western Ghats. - Current Science 100: 552558.

Karthick, B.; TAYlor, J.C.; Mahesh, M.K. \& Ramachandra, T.V. (2010): Protocols for Collection, Preservation and Enumeration of Diatoms from Aquatic Habitats from Water Quality Monitoring in India. - The IUP Journal of Soil and Water Science 3: 25-60.

Kobayasi, H. (1997): Comparative studies among four linear-lanceolate Achnanthidium species (Bacillariophyceae) with curved terminal raphe endings. - Nova Hedwigia 65: 147-164.

Kobayasi, H.; Idei, M.; Mayama, S.; Nagumo, T. \& Osada, K. (2006): H. Kobayasi's Atlas of Japanese Diatoms based on electron microscopy. - 531 pp., Uchida Rokakuho Publishing Co., Ltd, Tokyo.

Krammer, K. \& Lange-Bertalot, H. (1991): Bacillariophyceae. 4. Teil: Achnanthaceae, Kritische Ergänzungen zu Navicula (Lineolatae) und Gomphonema. - In Ettl, H.; Gärtner, G.; Gerloff, J.; Heynig, H. \& Mollenhauer, D. (eds): Süßwasserflora von Mitteleuropa, Vol. 2/4. - pp. 1-43, Stuttgart: Gustav Fischer.

KÜTZING, F.T. (1833): Synopsis Diatomacearum oder Versuch einer systematischen Zusammenstellung der Diatomeen. - Linnaea 8: 529-620, pls. XIII-XIX.

Lange-Bertalot, H. (1999): Neue Kombinationen von Taxa aus Achnanthes Bory (sensu lato). - In: LANGE-BERTALOT, H. (ed.): Iconographia Diatomologica. Annotated Diatom Micrographs, Vol. 6., Phytogeography-Diversity-Taxonomy. - pp. 276-289, Koeltz Scientific Books, Königstein, Germany.

MacGillivary, M. L. \& Ehrman, J. M. (2011): A readily available SEM substrate for a random orientation of diatom frustules. - Diatom Research 26: 321-323.

Monnier, O.; Lange-Bertalot, H.; Rimet, F.; Hoffmann, L. \& Ector, L. (2004): Achnanthidium atomoides sp. nov., a new diatom from the Grand-Duchy of Luxembourg. - Vie et Milieu 54:127-136.

Moser, G.; Lange-Bertalot, H. \& Metzeltin, D. (1998): Insel der Endemiten Geobotanisches Phänomen Neukaledonien (Island of endemics New Caledonia - a geobotanical phenomenon). - Bibliotheca Diatomologica 38: 1-464.

Moser, G.; Steindorf, A. \& Lange-Bertalot, H. (1995): Neukaledonien Diatomeenflora einer Tropeninsel, Revision der Collection Maillard und Untersuchung neuen Materials. - Bibliotheca Diatomologica 32: $1-340$.

Novais, M.H.; JÜttner, I.; Van de ViJver, B.; Morais, M.M.; Hoffmann, L. \& Ector, L.(2015): Morphological variability within the Achnanthidium minutissimum species complex (Bacillariophyta): comparison between the type material of Achnanthes minutissima and related taxa, and new freshwater Achnanthidium species from Portugal. - Phytotaxa 224: 101-139.

Pinseel, E.; Vanormelingen, P.; Hamilton, P.B.; Vyverman, W.; Van de Vijver, B. \& Kopalova, K. (in press): Molecular and morphological characterization of the Achnanthidium minutissimum complex (Bacillariophyta) in Petuniabukta (northern Billefjorden, Spitsbergen, high Arctic) including the description of A. digitatum sp. nov. - European Phycological Journal.

Ponader, K.C. \& Potapova, M.G. (2007): Diatoms from 
the genus Achnanthidium in flowing waters of the Appalachian Mountains (North America): Ecology, distribution and taxonomic notes. - Limnologica 37: 227-241.

Potapova, M. \& Hamilton, P.B. (2007): Morphological and ecological variation within the Achnanthidium minutissimum (Bacillariophyceae) species complex 1. Journal of Phycology 43: 561-575.

Potapova, M.G. \& Ponader, K.C. (2004): Two common North American diatoms, Achnanthidium rivulare sp. nov. and A. deflexum (Reimer) Kingston: Morphology, ecology and comparison with related species. Diatom Research 19: 33-57.

Potapova, M. (2009): Achnanthidium deflexum. - In Diatoms of the United States. Retrieved June 20, 2016, from http://westerndiatoms.colorado.edu/taxa/species/ achnanthidium_deflexum

Rabenhorst, L. (1861-1882): Die Algen Europas, Fortsetzung der Algen Sachsens, resp. - Mittel-Europas. Decades I-CIX, numbers 1-1600 (or 1001-2600). Dresden

Round, F.E. \& BukhtiYARova, L. (1996): Four new genera based on Achnanthes (Achnanthidium) together with a re-definition of Achnanthidium. - Diatom Research 11: $345-361$.

Simonsen, R. (1987): Atlas and Catalogue of the Diatom Types of Friedrich Hustedt, Vol. 2. - 395 pls., J. Cra- mer, Berlin \& Stuttgart.

TAylor, J.C.; Morales, E.A. \& Ector, L. (2011): Achnanthidium standeri (Cholnoky) comb. nov. and Achnanthidium taiaense (J.R. Carter \& Denny) comb. nov., two new combinations of morphologically similar Achnanthidium species from Africa. - Archiv für Hydrobiologie, Algological Studies 136/137:151-166.

Van de Vijver, B.; Ector, L.; Beltrami, M.E.; De Haan, M.; Falasco, E.; Hlúbiková, D.; Jarlam, A.; Kelly, M.; Novais, M.H. \& WoJTaL, A.Z. (2011a): A critical analysis of the type material of Achnanthidium lineare W. Sm. (Bacillariophyceae). - Archiv für Hydrobiologie, Algological Studies 136/137:167-191.

Van de Vijver, B.; Jarlman, A.; Lange-Bertalot, H.; Mertens, A.; De HaAn, M. \& Ector, L. (2011b): Four new European Achnanthidium species (Bacillariophyceae). -Archiv für Hydrobiologie, Algological Studies 136/137:193-210.

Wojtal, Z.A.; Lange-Bertalot, H.; Nautiyal, R.; Verma, J. \& Nautiyal, P. (2010): Achnanthidium chitrakootense spec. nov from Rivers of Northern and Central India. - Polish Botanical Journal 55: 55-64.

Zidarova, R.; Van De Vijver, B.; Mataloni, G.; Kopalova, K. \& Nedbalova, L. (2009): Four new freshwater diatom species (Bacillariophyceae) from Antarctica. - Cryptogamie Algologie 30: 295-310.
(C) Czech Phycological Society (2017)

Received February 4, 2016

Accepted July 7, 2016 